\title{
THE MATHEMATICAL MODELLING OF THE DYNAMICS OF SYSTEMS WITH REDUNDANT COORDINATES IN THE NEIGHBORHOOD OF STEADY MOTIONS
}

\author{
A.Ya. Krasinskiy, A.N. Ilyina \\ Moscow Aviation Institute, Moscow, Russian Federation \\ E-mail: krasinsk@mail.ru, happyday@list.ru
}

\begin{abstract}
This paper describes a method of use of equations in M.F. Shul'gin's form in Lagrangian variables for steady motion stability and stabilization problems of systems with geometric constraints. These equations of motion are free from Lagrange multipliers; we substantiate their advantage for solving stability and stabilization problems. Depended coordinates corresponding to zero solutions of characteristic equation are allocated in the disturbed equations of motion. These variables are necessarily present in systems with geometric constraints for any control method. It is suggested to present equations of motion in Routh variables for finding stabilizing control coefficients; Lagrangian variables are more useful for constructing an estimation system of object state. In addition to previous results, we evaluate the ability to reduce the dimension of measured output signal obtained in conformity with the chosen modelling method. Suppose the state of system is under observations and the dimension of measurement vector is as little as possible. Stabilizing linear control law is fulfilled as feedback by the estimation of state. We can determine uniquely the coefficients of linear control law and estimation system can be determined uniquely by solving of the corresponding linear-quadratic problems for the separated controllable subsystems using the method of N.N. Krasovsky. The valid conclusion about asymptotical stability of the original equations is deduced using the previously proved theorem. This theorem is based on the nonlinear stability theory methods and analysis of limitations imposed by the geometric constraints on the initial disturbances.
\end{abstract}

Keywords: geometric constraints; redundant coordinates; M.F. Shul'gin's equations; stability; stabilization; steady motion.

\section{Introduction}

Working out of control methods for nonlinear dynamic systems (control "in the large" [1]) is a typical issue both of modern control theory and technical practice. At the same time optimal utilization (energy, informational, computational and so on) at every mode of systems operation remains the most significant requirement for the modern and perspective automation. In this context, an optimization that is realized in real time during a control process becomes the central problem of the modern stability theory.

In practice, information about an object state is presented as a measurement vector. Generally, the dimension of this vector is much less then the dimension of the state variables vector. So an important stage of applied problems solution is analysis of experimental data to make estimation of the controlled object state optimal and suboptimal [1,2]. Thus, constructing of nonlinear mathematical models and practical application methods are required for control analysis of modern technical devices. The methods are used for possibly complete employment of properties of an object proper (without any additional actions) motions (modes of operation), reducing the number of equipped actuators (dimension of control), and for decreasing measuring information quantity for control law design. 


\section{Review of Previous Results}

There are many alternatives to make a valid choice of a dynamics modelling method for a certain class of problems in analytical mechanics. Ease of use and simplicity of the model directly depends on the chosen form of equations of motion and the type of variables these equations consider.

As it is well known [3, p. 5-6], Lagrangian, Hamilton's variables or some other parameters can be assumed as main variables describing the state of a mechanical system with independent Lagrange's coordinates. Routh suggested to use a combination of Lagrangian and Hamilton's variables. Routh's equations are equal to both equations presented in Lagrange's form and equations presented in Hamilton's form [3, p. 7]. Which method you use will be based upon your requirements.

If a system is a subject to constraints it makes the procedure of a choice of the most suitable generalized coordinates more complicated. In the article it is supposed that configuration of a system is restricted by geometric constraints. In numerous actual technical tasks, particularly, in the problems of control for multilink manipulators and other mechanotronic systems it is advisable [4-8] to describe configuration of mechanical component of the system by $n+m$ parameters, where $n$ is the number of the system degrees of freedom.

Then $m$ of these $n+m$ parameters are called redundant coordinates. There are $m$ independent equations that include these $n+m$ parameters.

$$
F_{k}\left(q_{1}, \ldots q_{n+m}\right)=0, \quad k=\overline{1, m} ; \quad \operatorname{rank} \frac{\partial\left(F_{1}, \ldots, F_{m}\right)}{\partial\left(q_{1}, \ldots q_{n+m}\right)}=m .
$$

Eliminating of the dependent coordinates from (1) is quite difficult and in many cases leads to cumbersome formulas, especially when trigonometrical functions [8, p. 288] are included in the equations.

It is useful to consider systems with geometric constraints as systems with redundant coordinates. Numerous works on analytical mechanics were devoted to the dynamics of such systems. At the same time the stability and stabilization problems of steady motion have not been studied enough for systems with redundant coordinates despite the great theoretical and practical significance.

Different forms of equations of motion [4-7] were analyzed in $[9,10]$ for systems with geometric constraints. It was shown that accurate mathematical model can be constructed relatively simple if equations in M.F. Shul'gin's form are used. It is also necessary to take into account geometric constraint equations differentiated once with respect to time. Thus, in general, a common examination methodology for the stability and stabilizations of steady motions problems was created for systems with geometric constraints. Theorem 1 about asymptotical stability was proved in [10] using the theory of critical cases [11-13] and taking into account the restrictions on the initial disturbances. It was proved in theorem 1 that an equilibrium position of a system with redundant coordinates is asymptotically stable if the number of zero roots of characteristic polynomial is equal to the number of constraints and the real parts of the other roots are strictly negative. A number of theorems was proved [14] about the sufficient conditions of solvability by the method $[15,16]$ for stabilization problems on the assumption of incomplete state information. These theorems are based on theorem 1 and Malkin's theorem about stability at permanent acting disturbances [12, p. 315-317]. Effectiveness of the developed method was shown [17] by the 
example of an accurate solving the equilibrium position stability and stabilization problem of one of the most popular bench system called BALL AND BEAM $[18,19]$.

\section{Problem Statement}

In general, considering systems in Routh's variables essentially simplifies $[3,10$, 14-16, 20-22] the procedure of linear stabilizing control coefficients determination for stabilization problems. But Routh's variables are very disadvantageous [21,22] for the control implementation while solving the asymptotic stability problems with respect to all variables on the assumption of incomplete state information. In this case required information cannot be obtained directly from the information sensors. Using Lagrangian variables gives additional abilities to reduce the dimension of measuring vector. But the procedure of stabilizing control coefficients determination is essentially more complicated if Lagrangian variables are used. Application of this variables considerably complicates the analysis of original (nonlinear) equations structure in the system closed by the designed control law. When control acts on a part of components of a cyclic coordinates vector in any way the number of zero roots of the characteristic equation is more then the number of geometric constraint equations.

In the work we suggest the approach based on application of different mathematical models of the same controlled mechanical system at different stages. Routh's variables can be used to design the control law that stabilizes the prescribed undisturbed motion. Lagrangian variables are handy for getting the information about the state of the system. The first stage, the determination of the control law coefficients when the dynamics is described in Routh's variables, has been studied [14-16] quite extensive. So this work is devoted to the constructing of a nonlinear system dynamics model for systems with geometric constraints in general case if equations of motion are presented in Lagrangian variables. Then we develop the method $[15,16,21]$ for dataware of the control loop in the stabilization problem on the assumption of incomplete state information.

\section{M.F. Shul'gin's Equations in Lagrange's Variables}

\subsection{General Case}

Suppose configuration of a mechanical system is specified by parameters $q_{1}, \ldots, q_{n+m}$, where $n$ is the number of the system degrees of freedom. The system configuration is limited by $m$ independent relations (1) (geometric constraints) between $q_{1}, \ldots q_{n+m}$. Without loss of generality coordinates $q_{n+1}, \ldots q_{n+m}$ can be considered as redundant. For convenience, introduce some vectors (the prime denotes transposition):

$$
r^{\prime}=\left(q_{1}, \ldots, q_{n}\right), \quad s^{\prime}=\left(q_{n+1}, \ldots q_{n+m}\right), \quad q^{\prime}=\left(r^{\prime}, s^{\prime}\right), \quad F^{\prime}=\left(F_{1}, \ldots, F_{m}\right)
$$

Then, in the vector-matrix form equations (1) can be written as

$$
F\left(r^{\prime}, s^{\prime}\right)=0 .
$$

Kinematic (holonomic) constraints can be obtained by differentiating (3) with respect to time:

$$
\frac{\partial F}{\partial r^{\prime}} \dot{r}+\frac{\partial F}{\partial s^{\prime}} \dot{s}=0
$$


The depended velocities vector can be expressed from (4):

$$
\dot{s}=-\left(\frac{\partial F}{\partial s^{\prime}}\right)^{-1} \cdot\left(\frac{\partial F}{\partial r^{\prime}}\right) \dot{r}=B(q) \dot{r}, \quad B(q)=-\left(\frac{\partial F}{\partial s^{\prime}}\right)^{-1} \cdot\left(\frac{\partial F}{\partial r^{\prime}}\right) .
$$

The general view of the kinetic energy is:

$$
T=T_{2}+T_{1}+T_{0}=\frac{1}{2} \dot{q}^{\prime} \tilde{a}(q) \dot{q}+\tilde{d}^{\prime}(q) \dot{q}+T_{0}(q),
$$

where $\tilde{a}=\left(\begin{array}{cc}\tilde{a}_{r r} & \tilde{a}_{r s} \\ \tilde{a}_{s r} & \tilde{a}_{s s}\end{array}\right)$ is a symmetric matrix,

$$
\begin{gathered}
\tilde{a}_{r r}(q)=\left(\begin{array}{ccc}
\tilde{a}_{11}(q) & \cdots & \tilde{a}_{1 n}(q) \\
\vdots & \vdots & \vdots \\
\tilde{a}_{n 1}(q) & \cdots & \tilde{a}_{n n}(q)
\end{array}\right), \quad \tilde{a}_{r s}(q)=\left(\begin{array}{ccc}
\tilde{a}_{1(n+1)}(q) & \cdots & \tilde{a}_{1(n+m)}(q) \\
\vdots & \vdots & \vdots \\
\tilde{a}_{n(n+1)}(q) & \cdots & \tilde{a}_{n(n+m)}(q)
\end{array}\right), \\
\tilde{a}_{s r}(q)=\tilde{a}_{r s}^{\prime}(q), \quad \tilde{a}_{s s}(q)=\left(\begin{array}{ccc}
\tilde{a}_{(n+1)(n+1)}(q) & \cdots & \tilde{a}_{(n+1)(n+m)}(q) \\
\vdots & \vdots & \vdots \\
\tilde{a}_{(n+m)(n+1)}(q) & \cdots & \tilde{a}_{(n+m)(n+m)}(q)
\end{array}\right), \quad \tilde{d}(q)=\left(\begin{array}{c}
\tilde{d}_{r} \\
\tilde{d}_{s}
\end{array}\right) .
\end{gathered}
$$

Eliminate the depended velocities (5) from expression (6) for the kinetic energy:

$$
\begin{gathered}
T^{*}(q, \dot{r})=T_{2}^{*}+T_{1}^{*}+T_{0}=\frac{1}{2} \dot{r}^{\prime} a(q) \dot{r}+d^{\prime}(q) \dot{r}+T_{0}(q) \\
a(q)=\tilde{a}_{r r}+2 \cdot \tilde{a}_{r s} B+B^{\prime} \tilde{a}_{s s} B, \quad d^{\prime}(q)=\tilde{d}_{r}^{\prime}+\tilde{d}_{s}^{\prime} B
\end{gathered}
$$

Suppose the system is affected by potential forces with energy $\Pi(q)$ and nonpotential position forces $\tilde{Q}_{r}(q, \dot{q}), \quad \tilde{Q}_{s}(q, \dot{q})$ corresponded to coordinates $r, s$. Let $Q_{r}^{*}(q, \dot{r})$ and $Q_{s}^{*}(q, \dot{r})$ denote the nonpotential forces after eliminating the dependent velocities using (5). Then the vector-matrix equations in M.F. Shul'gin's form [4] in Lagrangian variables can be written as

$$
\frac{d}{d t} \frac{\partial L^{*}}{\partial \dot{r}}-\frac{\partial L^{*}}{\partial r}=Q_{r}^{*}+B^{\prime}(q)\left(\frac{\partial L^{*}}{\partial s}+Q_{s}^{*}\right)
$$

where $L^{*}(q, \dot{r})=T^{*}(q, \dot{r})-\Pi(q)$ is the Lagrange function.

Remark 1. Equations (8) can be considered as a special case of Voronetz equations for nonholonomic systems with integrable kinematic constraints. This fact gives an opportunity to apply all methods of researching nonholonomic systems dynamics. From the other side, this equations have fundamentally different structure due to the lack of nonholonomic terms. Consequently there are some interesting features, which should be examined.

\subsection{Shulgin's Equations in the Presence of Cyclic Coordinates}

Suppose there are cyclic coordinates in the sense of [4] among the independent parameters $q_{1}, \ldots, q_{n}$ describing the system configuration. Then, the explicit form of vector-matrix equations of motion must be deduced.

Let $\beta^{\prime}=\left(q_{l+1}, \ldots, q_{n}\right)$ denote a vector of cyclic coordinates and $\alpha^{\prime}=\left(q_{1}, \ldots, q_{l}\right)$ denote a vector with components consists of the rest of the independent coordinates. So the vector $r$ of the independent coordinates is: $r^{\prime}=\left(\alpha^{\prime} \beta^{\prime}\right)$. Then, since coordinates $\beta$ are cyclic

$$
\frac{\partial F}{\partial \beta}=0, \quad \frac{\partial B}{\partial \beta}=0, \quad \frac{\partial T}{\partial \beta}=0, \quad \frac{\partial \Pi}{\partial \beta}=0
$$


Consequently, the depended velocities are evaluated from geometric constraint equations (1) differentiated with respect to time as follows:

$$
\frac{\partial F}{\partial \alpha^{\prime}} \dot{\alpha}+\frac{\partial F}{\partial s^{\prime}} \dot{s}=0 \Rightarrow \dot{s}=-\left(\frac{\partial F}{\partial s^{\prime}}\right)^{-1}\left(\frac{\partial F}{\partial \alpha^{\prime}}\right) \dot{\alpha}=B_{\alpha}(\alpha, s) \dot{\alpha} .
$$

Let the kinetic energy have the form similar to (6) but here

$$
\tilde{a}(\alpha, s)=\left(\begin{array}{ccc}
\tilde{a}_{\alpha \alpha} & \tilde{a}_{\alpha \beta} & \tilde{a}_{\alpha s} \\
\tilde{a}_{\beta \alpha} & \tilde{a}_{\beta \beta} & \tilde{a}_{\beta s} \\
\tilde{a}_{s \alpha} & \tilde{a}_{s \beta} & \tilde{a}_{s s}
\end{array}\right), \quad q=\left(\begin{array}{c}
\alpha \\
\beta \\
s
\end{array}\right), \quad \tilde{d}=\left(\begin{array}{c}
\tilde{d}_{\alpha} \\
\tilde{d}_{\beta} \\
\tilde{d}_{s}
\end{array}\right) .
$$

After eliminating the dependent velocities using (10) the kinetic energy expression is:

$$
T^{*}=\frac{1}{2}\left(\begin{array}{ll}
\dot{\alpha}^{\prime} & \dot{\beta}^{\prime}
\end{array}\right)\left(\begin{array}{cc}
a_{\alpha \alpha} & a_{\alpha \beta} \\
a_{\beta \alpha} & a_{\beta \beta}
\end{array}\right)\left(\begin{array}{c}
\dot{\alpha} \\
\dot{\beta}
\end{array}\right)+\left(\begin{array}{ll}
d_{\alpha}^{\prime} & d_{\beta}^{\prime}
\end{array}\right)\left(\begin{array}{c}
\dot{\alpha} \\
\dot{\beta}
\end{array}\right)+T_{0},
$$

where

$$
\begin{gathered}
a_{\alpha \alpha}=\tilde{a}_{\alpha \alpha}+2 \tilde{a}_{\alpha s} B_{\alpha}+B_{\alpha}^{\prime} a_{s s} B_{\alpha} ; \quad a_{\alpha \beta}=\tilde{a}_{\alpha \beta}+B_{\alpha}^{\prime} \tilde{a}_{s \beta} ; \quad a_{\beta \alpha}=a_{\alpha \beta}^{\prime} ; \\
a_{\beta \beta}=\tilde{a}_{\beta \beta} ; \quad d_{\alpha}^{\prime}=\tilde{d}_{\alpha}^{\prime}+d_{s}^{\prime} B_{\alpha} ; \quad d_{\beta}^{\prime}=\tilde{d}_{\beta}^{\prime} .
\end{gathered}
$$

Lagrange function is $L^{*}(\alpha, s, \dot{\alpha}, \dot{\beta})=T^{*}-\Pi$. If there are not nonpotential forces corresponded to the cyclic coordinates equations can be written as

$$
\frac{d}{d t} \frac{\partial L^{*}}{\partial \dot{\alpha}}-\frac{\partial L^{*}}{\partial \alpha}=Q_{\alpha}^{*}+B_{\alpha}^{\prime}\left(\frac{\partial L^{*}}{\partial s}+Q_{s}^{*}\right) ; \quad \frac{d}{d t} \frac{\partial L^{*}}{\partial \dot{\beta}}=0 .
$$

It is handy to write equations (12) in the scalar form for the further analysis of the system:

$$
\begin{gathered}
a_{\gamma \delta} \ddot{q}_{\delta}+a_{\gamma \sigma} \ddot{q}_{\sigma}+\left(\frac{\partial a_{\gamma \delta}}{\partial q_{\chi}}+\frac{\partial a_{\gamma \delta}}{\partial q_{\mu}} B_{\mu \chi}-\frac{1}{2} \frac{\partial a_{\chi \delta}}{\partial q_{\gamma}}-\frac{1}{2} B_{\mu \gamma} \frac{\partial a_{\chi \delta}}{\partial q_{\mu}}\right) \dot{q}_{\chi} \dot{q}_{\delta}+ \\
+\left(\frac{\partial a_{\gamma \sigma}}{\partial q_{\chi}}+\frac{\partial a_{\gamma \sigma}}{\partial q_{\mu}} B_{\mu \chi}-\frac{\partial a_{\chi \sigma}}{\partial q_{\gamma}}-B_{\mu \gamma} \frac{\partial a_{\chi \sigma}}{\partial q_{\mu}}\right) \dot{q}_{\chi} \dot{q}_{\sigma}-\frac{1}{2}\left(\frac{\partial a_{\tau \sigma}}{\partial q_{\gamma}}+B_{\mu \gamma} \frac{\partial a_{\tau \sigma}}{\partial q_{\mu}}\right) \dot{q}_{\tau} \dot{q}_{\sigma}+ \\
+\left(\frac{\partial d_{\gamma}}{\partial q_{\chi}}+\frac{\partial d_{\gamma}}{\partial q_{\mu}} B_{\mu \chi}-\frac{\partial d_{\chi}}{\partial q_{\gamma}}-B_{\mu \gamma} \frac{\partial d_{\chi}}{\partial q_{\mu}}\right) \dot{q}_{\chi}-\left(\frac{\partial d_{\sigma}}{\partial q_{\gamma}}+B_{\mu \gamma} \frac{\partial d_{\sigma}}{\partial q_{\mu}}\right) \dot{q}_{\sigma}- \\
-\frac{\partial\left(T_{0}-\Pi\right)}{\partial q_{\gamma}}-B_{\mu \gamma} \frac{\partial\left(T_{0}-\Pi\right)}{\partial q_{\mu}}=Q_{\gamma}^{*}+B_{\mu \gamma} Q_{\mu}^{*} ; \\
a_{\xi \delta} \ddot{q}_{\delta}+a_{\xi \sigma} \ddot{q}_{\sigma}+\left(\frac{\partial a_{\xi \delta}}{\partial q_{\chi}}+\frac{\partial a_{\xi \delta}}{\partial q_{\mu}} B_{\mu \chi}\right) \dot{q}_{\chi} \dot{q}_{\delta}+\left(\frac{\partial a_{\xi \sigma}}{\partial q_{\chi}}+\frac{\partial a_{\xi \sigma}}{\partial q_{\mu}} B_{\mu \chi}\right) \dot{q}_{\chi} \dot{q}_{\sigma}+ \\
+\left(\frac{\partial d_{\xi}}{\partial q_{\chi}}+\frac{\partial d_{\xi}}{\partial q_{\mu}} B_{\mu \chi}\right) \dot{q}_{\chi}=0 .
\end{gathered}
$$

Repeated indexes are summed over the values: $\gamma, \delta, \chi=1, \ldots, l ; \quad \xi, \sigma, \tau=l+$ $1, \ldots, n ; \mu, \kappa=n+1, \ldots, n+m$. In addition to equations (13) it is necessary to take into account differentiated geometric constraint equations (10) or in the scalar form

$$
\dot{q}_{\mu}=B_{\mu \chi} \dot{q}_{\chi}
$$

As obviously follows from (12) the system has cyclic integrals. Holonomic systems always $[3-5]$ have steady motions:

$$
\dot{\alpha}=0 ; \quad \alpha=\alpha_{0}=\text { const } ; \quad \dot{\beta}=c_{\beta}=\text { const } s=s_{0}=\text { const. }
$$


Constants $\alpha_{0}, c_{\beta}, s_{0}$ can be determined from

$$
\begin{gathered}
-\frac{1}{2}\left(\left(\frac{\partial a_{\tau \sigma}}{\partial q_{\gamma}}\right)_{0}+B_{\mu \gamma}(0)\left(\frac{\partial a_{\tau \sigma}}{\partial q_{\mu}}\right)_{0}\right) c_{\tau} c_{\sigma}-\left(\left(\frac{\partial d_{\sigma}}{\partial q_{\gamma}}\right)_{0}+B_{\mu \gamma}(0)\left(\frac{\partial d_{\sigma}}{\partial q_{\mu}}\right)_{0}\right) c_{\sigma}- \\
-\left(\frac{\partial\left(T_{0}-\Pi\right)}{\partial q_{\gamma}}\right)_{0}-B_{\mu \gamma}(0)\left(\frac{\partial\left(T_{0}-\Pi\right)}{\partial q_{\mu}}\right)_{0}=Q_{\alpha}^{*}\left(\alpha_{0}, s_{0}, 0, c_{\beta}\right)+B_{\mu \gamma}(0) Q_{\mu}^{*}\left(\alpha_{0}, s_{0}, 0, c_{\beta}\right) .
\end{gathered}
$$

Notation $(\ldots)_{0}$ и $B_{\rho \nu}(0)$ means that the expressions are calculated at a steady motion (15).

Remark 2. According to (16) there is a system of $l$ equations with respect to $n+m$ unknowns. It is necessary to take into consideration the geometric constraint equations (1) as before. Thus, the dimension of the manifold of holonomic systems steady motion is more or equal to $n-l$, where $n-l$ is the number of the cyclic coordinates.

Remark 3. Stability of the system motion in regard to cyclic impulses $\frac{\partial L^{*}}{\partial \dot{\beta}}$ directly follows from the equations of motion (12). Steady motion is not stable with respect to the cyclic coordinates in the general case (in the case of nonasymptotic stability with respect to the cyclic velocities). If we use control that provides an asymptotic stability with respect to the cyclic velocities, unperturbed steady motion will be stable with respect to the cyclic coordinates.

\section{Stabilization of a Steady Motion of Systems with Geometric Constraints under the Assumption of Incomplete State Information}

\subsection{Equations of Disturbed Motion in the Neighborhood of Steady Motions}

Introduce some initial disturbances: $\alpha=\alpha_{0}+x ; s=s_{0}+y ; \quad \dot{\beta}=c_{\beta}+w$ and assume that nonpotential forces corresponding to the coordinates of position have the following structure:

$$
\tilde{Q}_{\alpha}^{*}=f_{\alpha \alpha} \dot{\alpha}+f_{\alpha s} \dot{s}+g_{\alpha \alpha} \alpha+g_{\alpha s} s+\tilde{Q}_{\alpha}^{(2)} ; \quad \tilde{Q}_{s}^{*}=f_{s \alpha} \dot{\alpha}+f_{s s} \dot{s}+g_{s \alpha} \alpha+g_{s s} s+\tilde{Q}_{s}^{(2)} .
$$

Coefficients are calculated at a steady motion (15). Let the upper index (2) denote degree of lowest term in the expansion of the corresponding expression.

Remark 4. This form (17) of forces is chosen for simplicity. The suggested methodology allows to work with nonpotential forces of any form.

Then, using (13), the vector-matrix equations of disturbed motion with the first approximation separated can be written as

$$
\begin{gathered}
A_{1} \ddot{x}+A_{2} \dot{w}+\left(c_{\beta}^{\prime} \Psi_{1}+D_{\alpha}-F_{\alpha}\right) \dot{x}+\left(c_{\beta}^{\prime} \Psi_{2}+D_{\beta}-F_{\beta}\right) w+ \\
+\left[C_{1}+\left(\frac{\partial B_{\mu \gamma}}{\partial q_{\chi}}\right)_{0}\left(\frac{\partial W}{\partial q_{\mu}}\right)_{0}+B_{\alpha}^{\prime}(0) C_{2}+c_{\beta}^{\prime} \Psi_{2}^{1} c_{\beta}-G_{\alpha}\right] x+ \\
+\left[C_{3}+\left(\frac{\partial B_{\kappa \gamma}}{\partial q_{\mu}}\right)_{0}\left(\frac{\partial W}{\partial q_{\kappa}}\right)_{0}+B_{\alpha}^{\prime}(0) C_{4}+c_{\beta}^{\prime} \Psi_{2}^{2} c_{\beta}-G_{s}\right] y=X_{\alpha}^{(2)}(x, y, \dot{x}, w) ; \\
A_{3} \ddot{x}+A_{4} \dot{w}+\left(c_{\beta}^{\prime} \Psi_{3}+\tilde{D}_{\beta}\right) \dot{x}=X_{\beta}^{(2)}(x, y, \dot{x}, w) ; \\
\dot{y}=B_{\alpha}(0) \dot{x}+B_{\alpha}^{(1)}(x, y) \dot{x} ; \quad B_{\alpha}^{(1)}(x, y)=B_{\alpha}\left(\alpha_{0}+x, s_{0}+y\right)-B_{\alpha}(0) ;
\end{gathered}
$$


where

$$
\begin{gathered}
A_{1}=\left\|a_{\gamma \delta}(0)\right\|, \quad A_{2}=\left\|a_{\gamma \sigma}(0)\right\|, \quad A_{3}=\left\|a_{\sigma \delta}(0)\right\|, \quad A_{1}=\left\|a_{\sigma \tau}(0)\right\| ; \\
C_{1}=\left(\frac{\partial^{2} W}{\partial q_{\chi} \partial q_{\gamma}}\right)_{0}, \quad C_{2}=\left(\frac{\partial^{2} W}{\partial q_{\chi} \partial q_{\mu}}\right)_{0}, \quad C_{4}=\left(\frac{\partial^{2} W}{\partial q_{\mu} \partial q_{\kappa}}\right)_{0}, \quad C_{3}=C_{2}^{\prime} ; \\
D_{\alpha}=\left\|\frac{\partial d_{\gamma}}{\partial q_{\chi}}+\frac{\partial d_{\gamma}}{\partial q_{\mu}} B_{\mu \chi}-\frac{\partial d_{\chi}}{\partial q_{\gamma}}-B_{\mu \gamma} \frac{\partial d_{\chi}}{\partial q_{\mu}}\right\|_{0}, \quad D_{\beta}=\left\|-\left(\frac{\partial d_{\sigma}}{\partial q_{\gamma}}+B_{\mu \gamma} \frac{\partial d_{\sigma}}{\partial q_{\mu}}\right)\right\|_{0} \\
F_{\alpha}=f_{\alpha \alpha}+f_{\alpha s} B_{\alpha}(0)+B_{\alpha}^{\prime}(0) f_{s \alpha}+B_{\alpha}^{\prime}(0) f_{s s} B_{\alpha}(0), \quad F_{\beta}=f_{\alpha \beta}+B_{\alpha}^{\prime}(0) f_{s \beta} ; \\
G_{\alpha}=g_{\alpha \alpha}+B_{\alpha}^{\prime}(0) g_{s \alpha}, \quad G_{s}=g_{\alpha s}+B_{\alpha}^{\prime}(0) g_{s s}, \\
\Psi_{1}=\left\|\frac{\partial a_{\gamma \sigma}}{\partial q_{\chi}}+\frac{\partial a_{\gamma \sigma}}{\partial q_{\mu}} B_{\mu \chi}-\frac{\partial a_{\chi \sigma}}{\partial q_{\gamma}}-B_{\mu \gamma} \frac{\partial a_{\chi \sigma}}{\partial q_{\mu}}\right\|_{0}, \quad \Psi_{2}=\left\|\psi_{\tau \sigma}(0)\right\|, \\
\psi_{\tau \sigma}=-\left(\frac{\partial a_{\tau \sigma}}{\partial q_{\gamma}}+B_{\mu \gamma} \frac{\partial a_{\tau \sigma}}{\partial q_{\mu}}\right), \quad \Psi_{2}^{1}=\frac{1}{2}\left\|\frac{\partial \psi_{\tau \sigma}}{\partial q_{\chi}}\right\|_{0}, \quad \Psi_{2}^{2}=\frac{1}{2}\left\|\frac{\partial \psi_{\tau \sigma}}{\partial q_{\mu}}\right\|_{0}, \\
\Psi_{3}=\left\|\frac{\partial a_{\tau \sigma}}{\partial q_{\chi}}+\frac{\partial a_{\tau \sigma}}{\partial q_{\mu}} B_{\mu \chi}\right\|_{0}, \quad \tilde{D}_{\beta}=\left\|\frac{\partial d_{\tau}}{\partial q_{\chi}}+\frac{\partial d_{\tau}}{\partial q_{\mu}} B_{\mu \chi}\right\|_{0}, \quad W=\Pi-T_{0} .
\end{gathered}
$$

Then, following [21], determine variables corresponding to zero roots of the characteristic equation via the linear substitution [23]:

$$
z=y-B_{\alpha}(0) x .
$$

System (18) can be written as

$$
\begin{gathered}
A_{1} \ddot{x}+A_{2} \dot{w}+\left(\Phi_{\alpha}-F_{\alpha}\right) \dot{x}+\left(\Gamma-F_{\beta}\right) w+K x+S z=X_{\alpha}^{(2)}(x, z, \dot{x}, w) ; \\
A_{3} \ddot{x}+A_{4} \dot{w}+\Phi_{\beta} \dot{x}=X_{\beta}^{(2)}(x, y, \dot{x}, w), \quad \dot{z}=B_{\alpha}^{(1)}(x, z) \dot{x} ; \\
\Phi_{\alpha}=c_{\beta}^{\prime} \Psi_{1}+D_{\alpha}, \quad \Phi_{\beta}=c_{\beta}^{\prime} \Psi_{3}+\tilde{D}_{\beta}, \quad \Gamma=c_{\beta}^{\prime} \Psi_{2}+D_{\beta} ; \\
K=C_{1}+B_{\alpha}^{\prime}(0) C_{2}+C_{3} B_{\alpha}(0)+B_{\alpha}^{\prime}(0) C_{4} B_{\alpha}(0)+C^{B}+ \\
\quad+c_{\beta}^{\prime} \Psi_{2}^{1} c_{\beta}+c_{\beta}^{\prime} \Psi_{2}^{2} c_{\beta} B_{\alpha}(0)-G_{\alpha}-G_{s} B_{\alpha}(0) ; \\
C^{B}=\left(\frac{\partial B_{\mu \gamma}}{\partial q_{\chi}}\right)_{0}\left(\frac{\partial W}{\partial q_{\mu}}\right)_{0}+\left(\frac{\partial B_{\kappa \gamma}}{\partial q_{\mu}}\right)_{0}\left(\frac{\partial W}{\partial q_{\kappa}}\right)_{0} B_{\alpha}(0) .
\end{gathered}
$$

Notice that the matrices $G_{\alpha}, G_{\beta}, F_{\alpha}, F_{\beta}$ are composed of coefficients of linear in position coordinates and velocities terms of the nonpotential forces $Q_{\alpha}, Q_{s}$. Also it is necessary to focus attention on the matrix $C^{B}$. Its components depend on the second-order derivatives of geometric constraint equations (1) and can be lost in case of linearization of the geometric constraint equations. Components of the matrices $\Phi_{\alpha}, \Phi_{\beta}, \Gamma$ depend (in contrast to [20,24]) not only on the quadratic in velocities terms of the kinetic energy but on the linear in velocities of position coordinates terms, also.

Thus, we deduced the general form of the mathematical model for the stability and stabilization problems of steady motion for systems with geometric constraints and $n-l$ independent cyclic coordinates to nonlinear vector-matrix equations in Lagrangian variables. It is significant that for the construction of the model substitution (19) was executed to evaluate variables $z$ corresponding to zero roots of the characteristic equation, which are always present. Then, it is possible to deduce some statements about sufficient conditions of stability and instability of undisturbed stationary motion by determining the position of the other roots of the characteristic equation, analogously to [22]. In the case of instability it is possible to consider a stabilization problem of undisturbed motion. Instability takes place if $\operatorname{det} K<0$, in particular. The information about the state vector of the object can be incomplete. For definiteness let's consider one of the possible stabilization problem statements. For simplicity we examine the simplest variants of measurement vector structure. 


\subsubsection{Stabilization Control by the Cyclic Coordinates under the Assumption of the Incomplete Information About the State}

Suppose the control action $u$ is acted upon by all components of cyclic coordinates vector. Then system (20) with this control takes the form

$$
\begin{gathered}
A_{1} \ddot{x}+A_{2} \dot{w}+\left(\Phi_{\alpha}-F_{\alpha}\right) \dot{x}+\left(\Gamma-F_{\beta}\right) w+K x+S z=X_{\alpha}^{(2)}(x, z, \dot{x}, w) \\
A_{3} \ddot{x}+A_{4} \dot{w}+\Phi_{\beta} \dot{x}=u+X_{\beta}^{(2)} ; \quad \dot{z}=B_{\alpha}^{(1)}(x, z) \dot{x} .
\end{gathered}
$$

The canonical first order system derived from equations (20) is:

$$
\begin{aligned}
& \dot{\xi}=N \xi+V u+Z z+\Xi^{(2)}(\xi, z), \quad \dot{z}=B_{\alpha}^{(1)}(x, z) x_{1}, \quad \xi^{\prime}=\left(x^{\prime}, x_{1}^{\prime}, w^{\prime}\right) ;
\end{aligned}
$$

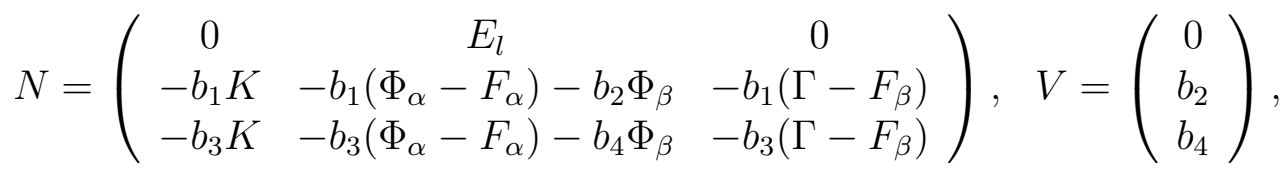

$$
\begin{aligned}
& Z=\left(\begin{array}{c}
0 \\
-b_{1} S \\
-b_{3} S
\end{array}\right), \quad \Xi^{(2)}=\left(\begin{array}{c}
0 \\
b_{1} X_{\alpha}^{(2)}+b_{2} X_{\beta}^{(2)} \\
b_{3} X_{\alpha}^{(2)}+b_{4} X_{\beta}^{(2)}
\end{array}\right), \quad A^{-1}=\left(\begin{array}{ll}
b_{1} & b_{2} \\
b_{3} & b_{4}
\end{array}\right),
\end{aligned}
$$

where $b_{1}, b_{2}, b_{3}, b_{4}$ are submatrices of dimensions $l \times l, l \times(n-l),(n-l) \times l$ and $(n-$ $l) \times(n-l)$ accordingly. Then introduce the simplest variants of matrices for coefficients of measurement vector linear approximation $\sigma_{i}=\Sigma_{i} \xi$ :

$$
\Sigma_{1}=\left(\begin{array}{lll}
E_{l} & 0 & 0
\end{array}\right) ; \quad \Sigma_{2}=\left(\begin{array}{lll}
0 & E_{l} & 0
\end{array}\right) ; \quad \Sigma_{3}=\left(\begin{array}{ccc}
0 & 0 & E_{n-l}
\end{array}\right) .
$$

The estimation system for obtaining the required information to form the stabilizing control is:

$$
\dot{\hat{\xi}}=N \hat{\xi}+V u-L_{k}\left(\Sigma_{k} \hat{\xi}-\sigma_{k}\right), \quad \hat{\xi}^{\prime}=\left(\hat{x}^{\prime}, \hat{x}_{1}^{\prime}, \hat{w}^{\prime}\right) .
$$

Theorem 1. If for system (22) the following conditions

$$
\begin{gathered}
\operatorname{rank}\left(\begin{array}{llll}
V & N V & N^{2} V \ldots N^{n+l-1} V
\end{array}\right)=n+l \\
\operatorname{rank}\left(\begin{array}{llll}
\Sigma_{k}^{\prime} & N^{\prime} \Sigma_{k}^{\prime} & \ldots & N^{n+l-1} \Sigma_{k}^{\prime}
\end{array}\right)=n+l ; \quad k=1,2,3,
\end{gathered}
$$

hold, then there is a linear control

$$
u_{k}=\Lambda_{k} \hat{\xi}_{k}
$$

stabilizing steady motion (15) to asymptotic stability with respect to all variables. Here $\hat{\xi}_{k}$ is estimation vector of a state of system (22) obtained from the measurement $\sigma_{k}$ by the solution of the stabilization dual problem

$$
\dot{\mu}_{k}=N^{\prime} \mu_{k}+\Sigma_{k}^{\prime} \nu_{k}, \quad \nu_{k}=L_{k}^{\prime} \mu_{k}, \quad k=1,2,3 .
$$

Proof. Separate the controllable subsystem

$$
\dot{\xi}=N \xi+V u
$$


from system (22). The observability condition (25) of subsystem (28) is the sufficient condition of the ability to determine uniquely the matrices $L_{k}$ in (23) by solving dual linear-quadratic problems using the method of N.N. Krasovsky [12, p. 475-514] for systems (27). Thus, if the conditions (24), (25) hold there are [25] matrices $\Lambda_{k}$ and $L_{k}$ such that the real parts of the roots of systems (28) and (23) characteristic equations are negative. The components of the matrices $\Lambda_{k}$ and $L_{k}$ can be determined uniquely by solving the corresponding linear-quadratic problems using the method of N.N. Krasovsky. As the structure of the closed nonlinear system (22) meets the conditions of theorem 1 [10] it is asymptotically stabilized by the control law (26).

Remark 5. Obviously, depending on $k$, we can say which rows of matrix $N$ are determinative for the observability conditions fulfillment: if $k=1$ (position coordinates perturbation) the first $l$ rows of $N$ are significant, if $k=2$ (cyclic velocities) then the next $l$ rows of $N$ and, finally, if $k=3$ (depended coordinates perturbation) then the last $n-l$ rows of $N$ are determinative.

Remark 6. In particular, the required condition for building the estimating system by the developed method cannot be fulfilled if $\Gamma-F_{\beta}=0$. An analogous result for holonomic systems with independent coordinates and the kinetic energy $T=T_{2}$ was obtained in [24]. In this case the structure of a measuring vector should be changed. One of the possible variants is adding to the vector some components of the velocities vector. In principle, in Lagrangian variables all components of this vector can be directly measured. Thus, the measured signal can comprise disturbances of the cyclic velocities, i.e., if the estimation system is not constructed in Routh's variables the structure of the measurement vector can be essentially different (compare with [14-16,21,22]). In the first approximation the matrix $N$ characterizes the proper (uncontrolled) motion of the system. Selection of components of velocities disturbances from the measurement vector depends on its structure. The minimal dimension of the measurement vector is determined [26] by the number of nontrivial invariant polynomials of the matrix and corresponded hardware. The dimension of the control vector due to the chosen way of stabilization and types of variables in the problem is equal to the number of the cyclic coordinates and cannot be decreased (compare with [14]).

\section{References}

1. Spravochnik po teorii avtomaticheskogo upravleniya [Guide on the Theory of Automatic Control]. Moscow, Nauka, 1987.

2. Kuntsevich V.M., Lychak M.M. Sintez sistem avtomaticheskogo upravleniya s pomoshch'yu funktsiy Lyapunova [System Synthesis of Automatic Control Sistem by Lyapunov Functions]. Moscow, Nauka, 1977.

3. Rumyantsev I.V. Ob ustoychivosti statsionarnykh dvizheniy sputnikov [About Stability of Stationary Motion of Satellites]. Moscow, USSR Academy of Science, 1967.

4. Shul'gin M.F. O nekotorykh differentsial'nykh uravneniyakh analiticheskoy dinamiki $i$ ikh integrirovanii [About Some Differential Equations of Analitical Dynamics and Their Integration]. Tashkent, Izdatelstvo SAGU, 1958.

5. Lur'e A.I. Analiticheskaya mehanika [Analytical Mechanics]. Moscow, Gosudarstvennoe izdatel'stvo fiziko-matematicheskoy literatury, 1961. 
6. Lyapunov A.M. Lekcii po teoreticheskoj mehanike [Lectures on Theoretical Mechanics]. Kiev, Naukova Dumka, 1982.

7. Novozhilov I.V., Zacepin M.F. [The Equations of Motion of Mechanic System with Redundant Variables]. Sbornik nauchno-metodicheskih statej po teoreticheskoj mehanike. V. 18 [The Miscellany of Scientific and Methodical Articles on Theoretical Mechanics. Issue 18], Moscow, Vysshaya shkola, 1987, pp. 62-66. (in Russian)

8. Zenkevich S.L., Jushhenko A.S. Osnovy upravleniya manipulyacionnymi robotami [The Basis of Manipulators Control]. Moscow, Bauman Moscow State Technical University, 2004.

9. Krasinskaya E.M., Krasinskiy A.Ya., Obnosov K.B. [About the Development of M.F. Shul'gin Scientific Methods as Applied to the Stability and Stabilization of Mechanotronic Systems with Redundant Coordinates]. Sbornik nauchno-metodicheskih statey po teoreticheskoy mehanike. V. 28 [The Miscellany of Scientific and Methodical Articles on Theoretical Mechanics. Vol. 28], Moscow, Publishing House of Lomonosov Moscow State University, 2012, pp. 169-184. (in Russian)

10. Krasinskaya E.M., Krasinskiy A.Ya. [Stability and Stabilization of Equilibrium State of Mechanical Systems with Redundant Coordinates]. Scientific Edition of Bauman MSTU: Science and Education, 2013, no. 3, pp. 347-376. (in Russian) DOI:10.7463/0313.0541146

11. Lyapunov A.M. Sobranie sochineniy. T. 2 [Collected Works. Vol. 2]. Moscow, Leningrad, USSR Academy of Science, 1956.

12. Malkin I.G. Teoriya ustoychivosti dvizhenija [The Theory of Dynamic Stability]. Moscow, Nauka, 1966, pp. 475-514.

13. Kamenkov G.V. Ustojchivost' $i$ kolebaniya nelineynyh sistem. Izbrannye trudy [The Stability and Oscillation of Nonlinear Systems. Selected Proc.]. Moscow, Nauka, 1972, vol. 2.

14. Krasinskiy A.Ya., Krasinskaya E.M. [On the Research Method of Stabilization Problem in the Assumption on the Incomplete Information About a System State]. Dinamika sistem $i$ processy upravleniya [The Proceedings of International Conference "Systems Dynamics and Control Processes"], Yekaterinburg, N.N. Krasovskii Institute of Mathematics and Mechanic, 2015, pp. 228-235. (in Russian)

15. Krasinskiy A.Ya. [About The Research Technique of Stability and Stabilization of Mechanical Systems Non-Isolated Steady Motions]. Ustoychivost' $i$ kolebaniya nelineynyh sistem [Selected Proc. of the VIII International Seminar "The Stability and Oscillation of Nonlinear Control Systems"], Moscow, V.A. Trapeznikov Institute of Control Sciences, 2004, pp. 97-103. (in Russian)

16. Krasinskaya E.M., Krasinskiy A.Ya. [About The Research Technique of Stability and Stabilization of Mechanical Systems with Redundant Coordinates Steady Motions]. Materialy $X I I$ Vserossiyskogo soveta po problemam upravleniya (VSPU - 2014) [The Proceedings of XII All-Russian Conference on the Control Problems], Moscow, V.A. Trapeznikov Institute of Control Sciences, 2014, pp. 1766-1778. (in Russian)

17. Krasinskaya E.M., Krasinskiy A.Ya. [Modelling of the Dynamics of GBB1005 Ball and Beam Educational Control System as a Controlled Mechanical System with a Redundant Coordinate]. Scientific Edition of Bauman MSTU: Scientific and Education, 2014, no. 1, pp. 282-297. (in Russian) DOI:10.7463/0114.0646446

18. Yu W. Nonlinear PD Regulation for Ball and Beam System. International Journal of Electrical Engineering Education, 2009, vol. 46, issue 1, pp. 59-73. DOI: 10.7227/IJEEE.46.1.5

19. Min-Sung Koo, Ho-Lim Choi, Jong-Tae Lim. Adaptive Nonlinear Control of a Ball and Beam System Using Centrifugal Force Term. International Journal of Innovative Computing, Information and Control, 2012, vol. 8, no. 9, pp. 5999-6009. 
20. Klokov A.S., Samsonov V.A. [About the Stabilization of Gyroscopically Constrained Systems with Coordinates of Pseudocyclic Trivial Steady Motions]. Journal of Applied Mathematics and Mechanics, 1985, vol. 49, issue 2, pp. 199-202. (in Russian)

21. Krasinskaya E.M., Krasinskiy A.Ya. [About the Stability and Stabilization of Non-Isolated Steady Motions of Mechanical Systems. Holonomical Systems]. Prikladnaya matematika $i$ mehanika: sbornik nauchnih trudov [Applied Mathematics and Mechanics: Miscellany of Scientific Works], Ul'yanovsk, Ulyanovsk State Technical University, 2011, pp. 301-322. (in Russian)

22. Krasinskiy A.Ya. [About Stabilization of Systems with Cyclic Coordinates Steady Motions]. Journal of Applied Mathematics and Mechanics, 1992, vol. 56, pp. 939-950. (In Russian)

23. Aiserman M.A., Gantmacher F.R. Stabilitaet der gleichgewichtslage in einem nichtholonomen system. Zeitschrift fur angewandte mathematik und mechanik, 1957, vol. 37, no. 1-2, pp. 74-75. DOI:10.1002/zamm.19570370112

24. Kalenova V.I., Morozov V.M., Salmina M.A. [For the Problem of Systems with Cyclic Coordinates Steady Motions]. Journal of Applied Mathematics and Mechanics, 1989, vol. 53, issue 5, pp. 707-713. (In Russian)

25. Kalman R.E., Falb P.L., Arbib M.A. Topics in Mathematical System Theory. N.Y., McGrawHill, 1969. 400 p.

26. Gabasov R., Kirillova F.M. Kachestvennaja teoriya optimal'nyh processov [Qualitative Theory of Optimum Processes]. Moscow, Nauka, 1971.

Received April 1, 2016

УДК 531.36

DOI: $10.14529 / \mathrm{mmp} 170203$

\section{О МАТЕМАТИЧЕСКОМ МОДЕЛИРОВАНИИ ДИНАМИКИ СИСТЕМЫ С ИЗБЫТОЧНЫМИ КООРДИНАТАМИ В ОКРЕСТНОСТИ УСТАНОВИВШИХСЯ ДВИЖЕНИЙ}

\section{А.Я. Красинский, А.Н. Илъина}

Московский авиационный институт, г. Москва

В переменных Лагранжа разрабатывается применение свободньх от множителей связей векторно-матричных уравнений движения к задачам устойчивости и стабилизации установившихся движений систем с геометрическими связями. В уравнениях возмущенного движения выделяются обязательно присутствующие при любом способе управления переменные - зависимые координаты, соответствующие нулевым корням характеристического уравнения. Обосновываются преимущества использования уравнений в форме, предложенной М.Ф. Шульгиным. Разрабатывается подход, основанный на применении модели в переменных Рауса на этапе определения коэффициентов стабилизирующего управления и модели в переменных Лагранжа для построения системы асимптотической оценки фазового состояния объекта. Анализируются дополнительные в сравнении с ранее полученными результатами возможности сокращения размерностей вектора измерений, доставляемые выбранным способом моделирования. Стабилизирующее линейное управление реализуется в виде обратной связи по оценке фазового состояния, полученной по измерению возможно меньшей размерности. 
Коэффициенты управления и системы оценивания определяются решением методом Н.Н. Красовского соответствующих линейно-квадратичных задач для выделяемых управляемых подсистем. Заключение об асимптотической устойчивости в силу этих нелинейных уравнений следует из ранее доказанной теоремы, основанной на методах нелинейной теории устойчивости и анализе условий, накладываемых геометрическими связями на начальные возмущения.

Ключевые слова: геометрические связи; избыточные координаты; уравнения М.Ф. Шульгина; устойчивость; стабилизация; стационарные движения.

\section{Литература}

1. Справочник по теории автоматического управления / под ред. А.А. Красовского. - М.: Наука, 1987.

2. Кунцевич, В.М. Синтез систем автоматического управления с помощью функций Ляпунова / В.М. Кунцевич, М.М. Лычак. - М.: Наука, 1977.

3. Румянцев, И.В. Об устойчивости стационарных движений спутников / И.В. Румянцев. М.: ВЦ АН ССCР, 1967.

4. Шульгин, М.Ф. О некоторых дифференциальных уравнениях аналитической динамики и их интегрировании / М.Ф. Шульгин. - Ташкент: Изд-во САГУ, 1958.

5. Лурье, А.И. Аналитическая механика / А.И. Лурье. - М.: Гос. изд-во физикоматематической литературы, 1961.

6. Ляпунов, А.М. Лекции по теоретической механике / А.М. Ляпунов. - Киев: Наукова думка, 1982.

7. Новожилов, И.В. Уравнения движения механических систем в избыточном наборе переменных / И.В. Новожилов, М.Ф. Зацепин // Сборник научно-методических статей по теоретической механике. Вып. 18. - М.: Высшая школа, 1987. - С. 62-66.

8. Зенкевич, С.Л., Ющенко, А.С. Основы управления манипуляционными роботами / С.Л. Зенкевич, А.С. Ющенко. - М.: Изд-во Московского государственного технического университета им. Н.Э. Баумана, 2004.

9. Красинская, Э.М. О развитии научных методов школы М.Ф. Шульгина в применении к задачам устойчивости и стабилизации равновесий мехатронных систем с избыточными координатами / Э.М. Красинская, А.Я. Красинский, К.Б. Обносов // Сборник научнометодических статей. Теоретическая механика. Т. 28. - М.: Изд-во Московского гос. ун-та, 2012. - С. 169-184.

10. Красинская, Э.М. Об устойчивости и стабилизации равновесия механических систем с избыточными координатами / Э.М. Красинская, А.Я. Красинский // Наука и образование: научное издание МГТУ им. Н.Э. Баумана. - 2013. - № 3. - С. 347-376.

11. Ляпунов, А.М. Собрание сочинений. Т. 2 / А.М. Ляпунов. - М.; Л.: Изд-во АН СССР, 1956. $-481 \mathrm{c}$.

12. Малкин, И.Г. Теория устойчивости движения / И.Г. Малкин. - М.: Наука, 1966.

13. Каменков, Г.В. Устойчивость и колебания нелинейных систем. Избранные труды. Т. 2 / Г.В. Каменков. - М.: Наука, 1972. - 215 с.

14. Красинский, А.Я. О методе исследования одного класса задач стабилизации при неполной информации о состоянии / А.Я. Красинский, Э.М. Красинская // Труды международной конференции «Динамика систем и процессы управления». - Екатеринбург: Изд-во Ин-та математики и механики им. Н.Н. Красовского Уральского отделения Российской академии наук, 2015. - С. 228-235. 
15. Красинский, А.Я. Об одном методе исследования устойчивости и стабилизации неизолированных установившихся движений механических систем / А.Я. Красинский // Избранные труды VIII Международного семинара «Устойчивость и колебания нелинейных систем управления». - М.: Ин-т проблем управления им. В.А. Трапезникова РАН, 2004. - C. 97-103.

16. Красинская, Э.М. Об одном методе исследования устойчивости и стабилизации установившихся движений механических систем с избыточными координатами / Э.М. Красинская, А.Я. Красинский // Материалы XII Всероссийского совещания по проблемам управления (ВСПУ-2014). - М.: Ин-т проблем управления им. В.А. Трапезникова РАН, 2014. - C. $1766-1778$.

17. Красинский, А.Я Моделирование динамики стенда GBB 1005 BALL AND BEAM как управляемой механической системы с избыточной координатой / А.Я. Красинский, Э.М. Красинская // Наука и образование: научное издание МГТУ им. Н.Э. Баумана. 2014. - № 1. - C. 282-297.

18. Yu, W. Nonlinear PD Regulation for Ball and Beam System / W. Yu // International Journal of Electrical Engineering Education. - 2009. - V. 46, № 1. - P. 59-73.

19. Min-Sung Koo. Adaptive Nonlinear Control of a Ball and Beam System Using Centrifugal Force Term / Min-Sung Koo, Ho-Lim Choi, Jong-Tae Lim // International Journal of Innovative Computing, Information and Control. - 2012. - V. 8, № 9. - P. 5999-6009.

20. Клоков, А.С. О стабилизируемости тривиальных установившихся движений гироскопически связанных систем с псевдоциклическими координатами / А.С. Клоков, В.А. Самсонов // Прикладная математика и механика. - 1985 - Т. 49, № 2. - С. 199-202.

21. Красинская, Э.М. Об устойчивости и стабилизации неизолированных установившихся движений механических систем. Голономные системы / Э.М. Красинская, А.Я. Красинский // Прикладная математика и механика: сборник научных трудов. - Ульяновск: Изд-во Ульяновского государственного технического университета, 2011. - С. 301-322

22. Красинский, А.Я. О стабилизации установившихся движений систем с циклическими координатами / А.Я. Красинский // Прикладная математика и механика. - 1992. № 56. - C. 939-950.

23. Aiserman, M.A. Stabilitaet der gleichgewichtslage in einem nichtholonomen system M.A. Aiserman, F.R. Gantmacher // Journal of Applied Mathematics and Mechanics. 1957. - V. 37, № 1-2. - P. 74-75.

24. Каленова, В.И. К задаче стабилизации установившихся движений систем циклическими координатами / В.И. Каленова, В.М. Морозов, М.А. Салмина // Прикладная математика и механика. - 1989. - Т. 53, № 5. - С. 707-713.

25. Калман, Р., Очерки по математической теории ситем / Р. Калман , П. Фалб , М. Арбиб. M.: УPCC, 2010.

26. Габасов, Р., Качественная теория оптимальных процессов / Р. Габасов, Ф.М. Кириллова. - М.: Наука, 1971. - 508 с.

Александр Яковлевич Красинский, доктор физико-математических наук, профессор, кафедра «Теория вероятностей», Московский авиационный институт (г. Москва, Российская Федерация), krasinsk@mail.ru.

Анастасия Николаевна Ильина, старший преподаватель, кафедра «Теория вероятностей», Московский авиационный институт (г. Москва, Российская Федерация), happyday@list.ru.

Поступила в редакиию 1 апреля 2016 г. 